\title{
Impact Of Import Tariff Policies On Rice Demand And Supply In Indonesia
}

\author{
Akhmad \\ Fakultas Ekonomi dan Bisnis \\ Universitas Muhammadiyah Makassar
}

\begin{abstract}
Indonesia's economic policies cannot be separated to its rice policies since rice is the staple food for Indonesian people. The paper aims to find out the impact of rice import tariff policies on rice demand and supply in Indonesia. The research uses time series data in 1981-2018. Data obtained are analyzed using econometric model with simultaneous equation system. Estimation results show that rice supply was positively and significantly influenced by grain rice price in farmer level, amount of rice production, and rice supply of the previous year. Meantime, domestic rice demand was negatively and significantly influenced by domestic rice price and positively and significantly influenced by domestic rice demand of the previous year. The result of policy simulation indicates that scenario of policy combination through an increase in rice import tariff and government purchase price brings a sizeable impact on the increase in domestic rice production and rice demand and supply. Therefore, Indonesia needs to conduct protection to farmers in the form of rice import tariff imposition as well as government purchase price.
\end{abstract}

Keywords: Rice Import Tariffs, Demand and Supply, Government Purchase Price

\section{INTRODUCTION}

Rice product is the main food product for Indonesian people. Hence, rice has important meaning for Indonesian people from the following stand points: First, rice is the main food thus it must continue to be available in a sufficient amount to fulfill people demand on rice; and second, rice is an employment source as well as income source for most of population, especially in rural areas.

Indonesia is currently the third highest rice consumption country in the world after the People's Republic of China and India. It is related to various reasons include 95\% Indonesia population use rice as their main food. The high dependency on rice causes rice production has a strategic economic value for Indonesian people as well as political and social values (Simatupang dan Rusastra 2004; Firdaus at.al 2008).

The high rice consumption in Indonesia, according to EOCD (2012); Christianto, E. (2013) is related to the average of Indonesian people consumes $124.89 \mathrm{~kg}$ rice per year. The consumption is twice larger than the average world consumption of $60 \mathrm{~kg} / \mathrm{year}$. Developing countries, including Indonesia, are generally set rice self-sufficiency as their agricultural development goal. Indonesia was once became a pioneer of agricultural development known as green revolution where agricultural production increase, especially rice, occurred in 1960s. Since then, farmers' prosperity level increased that significantly reduced the number of underprivileged population in rural areas. Food security also increased proven by rice surplus and as a consequence, Indonesia achieved food self-sufficiency in 1984 (Kasryno dan Pasandaran, 2004) 
Data from PDB in 2017 indicates that Food Sub-sector contribution is $3.22 \%$ of $9.90 \%$ total share of agricultural sector to Indonesia PDB (BPS, 2018). Rice commodity is the main crop commodity for Indonesia people of 260 million with growth rate of $1.31 \%$ and average rice consumption of $124.89 \mathrm{~kg} / \mathrm{capita} /$ year. Due to the population growth, increased rice production becomes a necessity as an effort to overcome lack of supply. According to Forecast Figure II from the result of Agricultural Ministry Coordinating Meeting and BPS, rice production in 2018 is estimated to increase by $4.81 \%$ or a production of 81.21 million ton (BPS, 2017;Kementerian Pertanian, 2017).

Based on the Regulation of the Minister of Finance of the Republic of Indonesia the rice import tariff is set $\mathrm{Rp} 450$ per $\mathrm{kg}$. Therefore, it is interesting to examine the impact of rice import tariff policy enforced by the government on Indonesian rice production and consumption.

\section{LITERATURE REVIEW}

Tariff and non-tariff policies basically impact the change in consumer surplus and producer surplus. The imposition of import tariff will benefit domestic producers since the import tariff will make the import price for similar commodities tends to be more expensive compared to the domestic price. The imposition of import tariff will cause an increase in product price in the importer country, a decrease in consumption, an increase in production, a decrease in import volume, and government revenue from the import tariffs ( Ellis, 1992).

In order to protect farmers from imported rice invasion, the government of Indonesia could take two actions, namely: non-tariff barrier and tariff barrier. At present, the government of Indonesia applies both instruments. Batabyal and Beladi (2001) stated that non-tariff and tariff policies will give impact on producer as well as consumer surplus. The imposition of import tariff, basically, will benefit the producers since it will make the imported product more expensive (Krugman, P.R., and M. Obsteld. 2002; Pindiyck, R.S., dan D.L. Rubinfeld 2007).

A comprehensive rice policy is succeeded to be designed in 2001. The result brings Inpres No. 9/2001 that prevails from January 1, 2002 and is followed by Inpres No. 13/2005 prevails in January 1, 2006. Rice export and import determination is one of regulation set to protect consumers' as well as farmers' interest. Husein Sawit and Rusastra (2005) explained that almost 80 percent rice farmer income in rich countries of OECD group member is originated from government encouragement. Hence, it is not fair if Indonesian farmers who manage a narrow land to compete in free trade world.

Indonesian rice policies aim to fulfill domestic rice demand through rice production increase by farmers (self-sufficiency). Therefore, import is intended to cover domestic rice insufficiency. Thus, it is important to know the amount of rice supply in Indonesia. Domestic rice production available for consumption becomes a benchmark in main food availability for Indonesian people (Hermawan Iwan, 2013; Akhmad, 2014).

\section{DATA AND METHODOLOGY}

The research used time series data in 1980-2017. The data were obtained from Bureau of Statistics, the Ministry of Agriculture, the Ministry of Industry and Trade, the Ministry of National Development Plan, the Logistic Affair Agency (Bulog), and the Ministry of Finance. Data collected consisted of: rice production and consumption, rice export and domestic price, world rice price, rice import, rice import tariff, and government purchase price.

Analysis model used in the research was simultaneous equation system model (econometric model). The developed model consisted of 6 (six) structural equations and 3 (three) identity 
equations. Data were then analyzed using a computer program of SAS Version 9.3. The simultaneous equation system developed comprised:

\section{Indonesian Rice Production}

Harvest area is influenced by grain rice price, corn price of the previous year as a substitute product, labor wage in agricultural sector, and rice plant area of the previous year. Hence, the harvest area equation is:

$$
\mathrm{LAP}_{\mathrm{t}}=\mathrm{a}_{0}+\mathrm{a}_{1} \mathrm{HGBt}+\mathrm{a}_{2} \mathrm{HJG}_{\mathrm{t}-1}+\mathrm{a}_{3} \mathrm{UTKSP}_{\mathrm{t}}+\mathrm{a}_{4} \mathrm{LAP}_{\mathrm{t}-1}+\mathrm{U}_{1}
$$

The magnitude and expected variable signs are: $\mathrm{a}_{1}, \mathrm{a}_{3}>0 ; \mathrm{a}_{2},<0$ and $0<\mathrm{a} 4<1$

Rice plant productivity is influenced by grain rice price in farmer level, urea fertilizer price, TSP fertilizer price, and productivity of the previous year. Thus, the rice productivity equation is:

$$
\mathrm{PPI}_{\mathrm{t}}=\mathrm{b}_{0}+\mathrm{b}_{1} \mathrm{HGB}_{\mathrm{t}}+\mathrm{b}_{2} \text { PUREA }_{\mathrm{t}}+\mathrm{b}_{3} \mathrm{PTSPt}+\mathrm{b}_{4} \mathrm{PPI}_{\mathrm{t}-1}+\mathrm{U}_{2}
$$

The magnitude and expected variable signs are: $b_{1},>0 ; b_{2}, b_{3}<0$ and $0<b 4<1$

Grain rice production in Indonesia is obtained by multiplying harvest area by rice plant productivity per hectare. Indonesian rice production equation is obtained from the multiplication of conversion number and rice production. Thus, the rice production equation is:

$$
\begin{gathered}
\text { QPPIt }=\mathrm{LAPt} \\
\text { PBIt }=\mathrm{QPPIt}^{*} \mathrm{Kt}
\end{gathered}
$$

\section{Indonesian Rice Supply and Demand}

Rice supply is assumed to be influenced by grain rice price in farmer level, the amount of domestic rice production, the amount of rice import, world rice price, and rice supply of the previous year. Rice supply equation is:

$$
\mathrm{QSBI}_{\mathrm{t}}=\mathrm{c}_{0}+\mathrm{c}_{1} \mathrm{HGR}_{\mathrm{t}}+\mathrm{c}_{2} \mathrm{QPPI} \mathrm{I}_{\mathrm{t}}+\mathrm{c}_{3} \mathrm{IBI}_{\mathrm{t}}+\mathrm{c}_{4} \mathrm{HBWRt}+\mathrm{c}_{5} \mathrm{QSBI}_{\mathrm{t}-1}+\mathrm{U}_{3}
$$

The magnitude and expected variable signs: $c_{1}, c 2, c 3, c 5>0$; and $c 4<0$

Rice demand is assumed to be influenced by: domestic rice price, corn price, income per capita, rice export, world rice price, flour price, and rice demand of the previous year. Rice demand equation is formulated:

$$
\mathrm{QDBI}_{\mathrm{t}}=\mathrm{d}_{0}+\mathrm{d}_{1} \mathrm{HBD}_{\mathrm{t}}+\mathrm{d}_{2} \mathrm{HJD}_{\mathrm{t}}+\mathrm{d}_{3} \mathrm{PPK}_{\mathrm{t}}+\mathrm{d}_{4} \mathrm{EXBIt}+\mathrm{d}_{5} \mathrm{HBWDt}+\mathrm{d}_{6} \mathrm{HTT}_{\mathrm{t}}+\mathrm{d}_{7} \mathrm{QDBI}_{\mathrm{t}-1}+\mathrm{U}_{4}
$$

The magnitude and expected variable signs: $d_{2}, d_{3}, d_{6}, d_{7}>0$; and $d_{1}, d_{4}, d_{5}<0$.

\section{Domestic Rice Price}

Grain rice price in farmer level is influenced by government purchase basic price as well as by Indonesian rice import, the amount of rice production, and grain rice price of the previous year.

$$
\mathrm{HGTP}_{\mathrm{t}}=\mathrm{e}_{0}+\mathrm{e}_{1} \mathrm{HDPP}_{\mathrm{t}}+\mathrm{e}_{2} \mathrm{IBI}_{\mathrm{t}}+\mathrm{e}_{3} \text { PBIt }+\mathrm{e}_{4} \mathrm{HGTPt}+\mathrm{U}_{5}
$$


The magnitude and expected variable signs: $\mathrm{e} 1,>0 ; \mathrm{e}_{2}, \mathrm{e}_{3}<0$ and

Indonesian rice price is influenced by domestic rice production, domestic rice demand, and world rice price, rice import tariff and domestic rice price of the previous year. The variables are formulated as follows.

$$
H B I_{t}=f_{0}+f_{1} P B I_{t}+f_{2} Q D B I+f_{3} H B W R_{t}+f_{4} T I I_{t}+f_{5} H B I_{t-1}+U_{6}
$$

The magnitude and expected variable signs: $\mathrm{f}_{2}, \mathrm{f}_{3}, \mathrm{f}_{4}>0 ; \mathrm{f}_{1}<0 ; 0<\mathrm{f}_{3}<1$

\section{Government Revenue}

Government revenue is a multiplication of number of imported rice and the amount of rice import tariff. Therefore, government revenue equation is an identity equation, which is as follows.

$$
\text { PPMRt }=\text { TIBIt }{ }^{*} J \text { BIt }
$$

\section{Model Estimation}

The model estimation result obtained that model was stated as over identified; thus, the appropriate estimation method used was 2SLS (Two stage Least Squares) method. This method is suitable for a sample that is relatively small and not sensitive to modification (Koutsoyiannis, 2003; Intriligator, 1978). The model can also be used for structural analysis, simulation, and forecasting. Data obtained were processed using computer software of SAS Version 9.3.

\section{Model Simulation}

Pindyck dan Rubinfield (1991) (Akhmad at al., 2012) stated that simulation was conducted for a variety of reasons such as for model testing and evaluation, historical policy analysis and forecasting. Simulation was performed to find out the impact of change in exogenous variables on endogenous variables in the model. In this study, the simulation was intended for historical policy analysis. Policy simulation in this study aimed to observe the impact of rice import tariff policy on rice demand and supply in Indonesia. There were three policy scenarios, spartial as well as combination, namely: (1) Increasing rice import tariff of $50 \%$, (2) Increasing government purchase basic price of $20 \%$, and (3) A combination of an increase in rice import tariff of $50 \%$ and an increase in government purchase basic price of $20 \%$.

\section{Model Estimation Result}

\section{RESEARCH RESULT}

Equation system model developed in the research had undergone several modifications until a model with a parameter estimation result performance representative to describe the impact of rice import tariff on rice demand and supply in Indonesia was found. The developed simultaneous equation system comprised six structural equations and three identity equations. Rice import tariff model estimation provided a passable result econometrically. In general, the model estimation result was adequate with coefficient of determination $\left(\mathrm{R}^{2}\right)$ indicated a result in the range of 0.69 and 0.92 . The exogenous variables were generally able to explain the endogenous variable. Therefore, the estimation result was sufficiently representative to describe rice import tariff phenomenon on rice demand and supply in Indonesia.

\section{Result of Rice Production, Demand, and Supply Model Estimation}

Rice production, demand, and supply model consisted of six structural equations and one identity equation comprised corn plant area equation, corn productivity equation, corn 
demand equation, rice supply equation, and domestic rice price equation. Each equation is explained in the following section.

\section{Rice Plant Area}

The result of parameter estimation indicated that harvest area was positively and significantly influenced by grain rice price in farmer level and harvest area of the previous year variables. Labor wage, however, had a positive yet insignificant influence and corn price variable had negative yet insignificant influence. All variables were inelastic to harvest area.

\section{Indonesian Rice Productivity}

Statistically, rice plant productivity was positively and significantly influenced by grain rice price in farmer level and grain rice productivity of the previous year. Fertilizer production factors gave the opposite value and direction of estimation parameter between TSP and Urea fertilizers price. TSP fertilizer price was directly proportional to productivity change since a decrease in fertilizer price will increase the use of fertilizer among farmers; thus, an increase in productivity. The finding was in line with Djulin, Syafa'at dan Kasryno (2005) found that it was related to the use of phosphor fertilizer that was still below the suggested dose, with 80 percent of the suggested dose in rice field and 76 percent in dry land, on average. In fact, in NTT, the use of fertilizer was only 20 percent in rice field and 28 percent in dry land. Phosphor fertilizer utilization that was still below the suggested dose was also related to the shift in the use of TSP fertilizer to SP-36 that had a difference in Phosphor element level, which was 45 percent in TSP to 36 percent in SP-36. In addition, farmers usually did not add the given fertilizer dose. On the contrary, an increase in Urea price that would decrease the fertilizer utilization evidently increased corn productivity. It suggested that urea fertilizer utilization in rice had exceeded the optimal point suggested; therefore, it was on a decline in the production curve. As a consequence, an additional dose would reduce rice productivity.

\section{Rice Supply}

Rice supply was positively and significantly influenced by grain price in farmer level, the amount of rice production, and rice supply of the previous year. Whereas, rice import had positive yet insignificant influence on Indonesian rice supply. Domestic rice price and world rice price had positive yet insignificant influence on domestic rice supply, whereas world rice price variable had negative yet insignificant influence. All explanatory variables did not responsive to domestic rice supply.

When domestic rice production increased, rice supply would increase, and vice versa. Likewise, when rice import increased, rice supply would increase; thus, domestic rice price would decrease. Hence, although domestic rice price had the opposite sign to the expected sign it was still normal since rice production response would be higher compared to rice price response to domestic rice supply.

\section{Domestic Rice Demand}

Domestic rice demand was negatively and significantly influenced by domestic rice price and rice demand of the previous year. Next, corn price, income per capita, and flour price variables had positive yet insignificant influence on domestic rice demand. Indonesian rice export and world rice price variables had negative yet insignificant influence on domestic rice demand. All parameters did not responsive to domestic rice demand. All directions and magnitudes of estimation parameter values were as expected. 
Table 1. Result of Model Estimation

\begin{tabular}{|c|c|c|c|c|c|c|}
\hline Equation & Variable & $\begin{array}{l}\text { Estimation } \\
\text { Parameter }\end{array}$ & T Value & $\operatorname{Pr}>t$ & $\begin{array}{c}\text { Short } \\
\text { Term } \\
\text { Elasticity } \\
\end{array}$ & $\mathrm{R}^{2}$ \\
\hline \multicolumn{7}{|c|}{ Rice Harvest Area Equation } \\
\hline Intersept & Intercept & 3608.949 & & & - & 0.74321 \\
\hline HGR & Grain rice price in farmer level & 4,7141 & 1.54 & 0.0382 & 0,2833 & \\
\hline HJG & Corn price & $-1,2867$ & -0.99 & 0.1347 & 0,1373 & \\
\hline UTKSP & Labor wage in agricultural sector & 3,4878 & 0.81 & 0.4259 & 0,0979 & \\
\hline LAPt-1 & Rice harvest area of the previous year & 0,4878 & 4.81 & 0.0021 & - & \\
\hline \multicolumn{7}{|c|}{ Indonesian Rice Plant Productiviy Equation } \\
\hline Intersept & Intercept & 161.1764 & & & & 0.84214 \\
\hline HGR & Grain rice price in farmer level & 0.23450 & 3.47 & 0.0474 & 0,1215 & \\
\hline PUREA & Urea fertilizer price & -0.32125 & -0.89 & 0.3856 & 0,0327 & \\
\hline PTSP & TSP fertilizer price & 0.21304 & 1.22 & 0.2367 & $-0,0213$ & \\
\hline PGI t-1 & Grain rice production of the previous year & 0.21304 & 3.22 & 0.0167 & - & \\
\hline \multicolumn{7}{|c|}{ Indonesian Rice Supply Equation } \\
\hline Intersept & Intercept & 1232.545 & & & & 0.92126 \\
\hline HGR & Grain rice price in farmer level & 201.873 & 3.25 & 0.0318 & 0,2676 & \\
\hline QPPI & Amount of Indonesian rice production & 20.179 & 1.35 & 0.0294 & 0,0598 & \\
\hline IBI & Indonesian rice import & 9.394 & 0.98 & 0.2105 & 0,3621 & \\
\hline HBWR & World rice price & -0.628 & 12.39 & 0.1285 & 0,1826 & \\
\hline QSBI $\mathrm{t}_{\mathrm{t}}$ & Indonesian rice supply of the previous year & 0.0743 & 4.533 & 0.0005 & - & \\
\hline \multicolumn{7}{|c|}{ Indonesian Rice Demand Equation } \\
\hline Intersept & Intercept & 433.508 .4 & & & & 0.89541 \\
\hline HBD & Domestic rice price & -417.543 & -4.47 & 0.0121 & $-0,3614$ & \\
\hline HJD & Corn price & 0.978369 & 0.123 & 0.1201 & 0,2207 & \\
\hline PPK & Income per capita & 1.134 .68 & 0.665 & 0.2101 & 0,0774 & \\
\hline EXBI & Indonesian rice export & -0.58000 & -0.143 & 0.2421 & $-0,2143$ & \\
\hline HBWD & World rice price & -0.23158 & -0.042 & 0.1213 & $-0,3243$ & \\
\hline HTT & Flour price & 0.14321 & 0.051 & 0.2193 & 0,0343 & \\
\hline QDBI $\mathrm{t}_{\mathrm{t}-1}$ & Rice demand of the previous year & 0.01225 & 4.134 & 0.0341 & - & \\
\hline \multicolumn{7}{|c|}{ Grain Rice Price in Farmer Level Equation } \\
\hline Intersept & Intercept & 16745.109 & & & & 0.72135 \\
\hline HDPP & Government purchase basic price & 0.32125 & 6.22 & 0.0006 & 0,432 & \\
\hline IBI & Indonesian rice import & -0.12163 & -2.32 & 0.1519 & $-0,1321$ & \\
\hline PBI & Indonesian rice production & -0.24314 & -0.51 & 0.3212 & -0.0321 & \\
\hline $\mathrm{HGTP}_{\mathrm{t}-1}$ & $\begin{array}{l}\text { Grain rice price in farmer level of the } \\
\text { previous year }\end{array}$ & 0.21321 & 4.32 & 0.0021 & - & \\
\hline \multicolumn{7}{|c|}{ Indonesian Rice Price Equation } \\
\hline Intersept & Intercept & 259.521 & & & & 0.69722 \\
\hline PBI & Indonesian rice production & -0.32115 & -0.041 & 0.8246 & $-0,1321$ & \\
\hline QDBI & Indonesian rice demand & 0.21363 & 0.532 & 0.0419 & 0,0401 & \\
\hline HBWR & World rice price & 0.78514 & 5.401 & 0.0021 & 0.0321 & \\
\hline TIBI & Indonesian rice import tariff & 0.21321 & 0.321 & 0.3212 & 0.1132 & \\
\hline HBIt-1 & Indonesian rice price of the previous year & 0.12321 & 4.656 & 0.0242 & - & \\
\hline
\end{tabular}

\section{Grain Rice Price in Farmer Level}

Rice price in farmer level was significantly and positively influenced by government purchase basic price, and grain rice price in farmer level of the previous year. In addition, rice import and Indonesian rice production variables had negative yet insignificant influence on grain rice price in farmer level. All parameters did not responsive to grain rice price in farmer level. All directions and magnitudes of estimation parameter values were as expected.

\section{Domestic Rice Price}

Domestic rice price was positively and significantly influenced by domestic rice demand, world rice price, and domestic rice price of the previous year. Rice import tariff had positive yet insignificant influence. In addition, Indonesian rice production had negative yet insignificant influence on domestic rice price. All estimation parameters were as expected in terms of the signs as well as magnitudes. All parameters were inelastic in a short term. 


\section{Import Tariff Policy Simulation}

Validation result of rice import tariff policy model obtained that all equations had a prediction value that could follow its historical data tendency properly that indicated by RMSPE value below 20 percent. It also occurred according to criteria based on U Theil value. All equations had U Theil value below 0.1 ; therefore, it can be implied that the model simulation followed its actual data properly.

Policy simulation carried out on rice import tariff policy model included: (1) the impact of an increase in rice import tariff of 50 percent, (2) the impact of an increase in subsidized government purchase price of 20 percent, (3) the impact of a combination of an increase in rice import tariff of $50 \%$ and an increase in government purchase price of 20 percent.

Table 2. Complete Result of Model Simulation of Import Tariff Policy Impact on Rice Production, Demand, and Supply in Indonesia

\begin{tabular}{|l|c|c|c|c|}
\hline \multirow{2}{*}{\multicolumn{1}{|c|}{ Variable }} & \multirow{2}{*}{ Basic Value } & \multicolumn{3}{c|}{ Simulation } \\
\cline { 3 - 5 } & & $\mathrm{S} 1$ & $\mathrm{~S} 2$ & $\mathrm{~S} 3$ \\
\hline Rice harvest area & 3189207 & $0.02 \%$ & $0.04 \%$ & $0.06 \%$ \\
Indonesian rice plant productivity & 23.897 & $0.21 \%$ & $0.45 \%$ & $0.61 \%$ \\
Indonesian supply & 7659568 & $-0.11 \%$ & $0.20 \%$ & $0.02 \%$ \\
Indonesian rice demand & 8250290 & $-0.07 \%$ & $0.12 \%$ & $0.01 \%$ \\
Grain Rice Price in Farmer Level & 7762135 & $0.28 \%$ & $1.74 \%$ & $1.81 \%$ \\
Indonesian rice price & 11854.4 & $0.18 \%$ & $-0.11 \%$ & $-0.01 \%$ \\
Indonesian grain Production & 7574321 & $0,17 \%$ & $0.23 \%$ & $0.29 \%$ \\
Indonesian rice production & 6264367 & $0,14 \%$ & $0.20 \%$ & $0.24 \%$ \\
Government revenue & 2342543 & $0,22 \%$ & $-0,07 \%$ & $0,17 \%$ \\
\hline
\end{tabular}

\section{The Impact of an Increase in Rice Import Tariff of 50 percent}

The first policy scenario (S1) was an increase in rice import tariff of 50 percent that resulted in an increase in rice plant area of 0.02 percent. Indonesian rice plant productivity increased by 0.21 percent, Indonesian rice supply decreased by 0.11 percent, domestic rice demand decreased by 0.07 percent, grain rice price in farmer level increased by 0.28 percent thus domestic rice price increased by 0.18 percent. Further, it caused Indonesian grain production increased by 0.17 percent, rice production increased by 0.14 percent, and government revenue from rice import tariff increased by 0.22 percent.

Theoretically, if government increased rice import tariff, then imported rice price increased; thus, rice import volume decreased. Due to the decrease in rice import volume, grain rice price in farmer level was expected to increase and in turn, an increase in rice plant productivity. As a consequence domestic rice productivity also increased. In addition, by increasing rice import tariff, government revenue and tariff increased.

\section{The Impact of an Increase in Government Purchase Price of 20 percent}

The second policy scenario (S2), which was an increase in government purchase price brought impact on the increase in rice plant area of 0.04 percent, rice plant productivity increased by 0.45 percent, Indonesian rice supply increased by 0.22 percent, domestic rice demand also increased by 0.12 percent, grain rice price in farmer level increased by 1.74 percent, and domestic rice price increased by 0.11 percent. Moreover, grain rice production increased by 0.23 percent, rice production increased by 0.20 percent, and finally government revenue decreased by 0.07 percent. 


\section{The Impact of an Increase in Government Purchase Price and Rice Import Tariff}

The third policy simulation (S3) was a combination of an increase in government purchase price of 20 percent and rice import tariff of $50 \%$. The combination gave impact on the increase in rice plant area of 0.06 percent. In addition, rice plant productivity increased by 0.61 percent that resulted in an increase in Indonesian rice supply of 0.02 percent as well as domestic rice demand of 0.01 percent, and grain rice price in farmer level of 1.81 percent but a decrease in domestic rice price of 0.01 percent. Further, Indonesian grain rice production increased by 0.29 percent and rice production increased 0.24 percent. Consequently, government revenue from rice import tariff decreased by 0.17 percent.

\section{Conclusion}

\section{CONCLUSION AND POLICY IMPLICATION}

According to the model estimation result and simulation of the impact of rice import tariff policies on rice demand and supply, conclusions could be drawn as follows.

1. Rice harvest area was positively and significantly influenced by grain rice price in farmer level and harvest area of the previous year variables. It indicated that rice price policy could encourage an increase in rice area. Meanwhile, rice plant productivity was significantly influenced by grain rice price in farmer level and grain rice productivity of the previous year. Therefore, government purchase price policy was required to maintain rice in farmer level.

2. Rice supply was positively and significantly influenced by grain rice price in farmer level, amount of rice production, and rice supply of the previous year. Meantime, domestic rice demand was negatively and significantly influenced by domestic rice price and positively and significantly influenced by domestic rice demand of the previous year. Further, domestic rice price was positively and significantly influenced by domestic rice demand, world rice price, and domestic rice price of the previous year.

3. Policy scenarios through an increase in rice import tariff of 50 percent and government purchase price of 20 percent gave impact on the increase in domestic rice production and domestic rice demand and supply. The scenario was the best scenario of the three policy scenarios conducted according to the amount of rice production, demand and supply.

\section{Policy Implication}

Policy recommendations proposed according to the analysis results based on the model estimation, model simulation and the impact of various policy alternatives on prosperity include:

1. Domestic rice price was unresponsive to national rice demand and supply as well as world price. It implied that domestic rice price was not formed by the market but by other factors, such as traders and importers. Hence, the government should monitor domestic rice marketing since rice farmers' bargaining position is low; thus, rice price formation at the market must receive supervision from the government.

2. Policy scenario of an increase in rice import tariff of 50 percent and government purchase price of 20 percent was the best scenario of the three scenarios conducted according to the rice production, demand, and supply. Therefore, the policy scenario could become the government's main priority in terms of national rice policy.

\section{References}

Akhmad, N.A.Achsani, M. Tambunan, S.A. Mulyo. 2012. Impact of Fiscal Policy on the Agricultural Development in an Emerging Economy: Case Study from the South Sulawesi, Indonesia. International Research Journal of Finance and Economics. Issue 96. p. 101.112.

Akhmad. 2014. Dampak Kebijakan Tarif Impor Beras Terhadap Surplus Produsen dan Konsumen. Jurnal Kebijakan Pembangunan. Edisi 01 Mei 2014. Hal. 14-24. 
Badan Pusat Statistik. 2017. Statistik Harga Produsen Beras di Penggilingan. Badan Pusat Statistik. Jakarta.

Badan Pusat Statistik. 2018. Statistik Indonesia. Badan Pusat Statistik. Jakarta.

Batabyal A. and H. Beladi. 2001. The Economics Of International Trade and The Environment. Lewis Publishers is an imprint of CRC Press LLC. New York.

Christianto Edward. 2013. Faktor Yang Memengaruhi Volume Impor Beras Di Indonesia.Jurnal Jibeka Volume 7

No 2 Agustus 2013: 38 - 43.

Ellis, F. 1992. Agricultural Policies in Developing Countries. Cambridge University Press, New York.

Hermawan Iwan. 2013. Analisis Perdagangan Beras Dan Ketahanan Pangan Di Negara-Negara Asia Tenggara. Jurnal Politica Vol. 4 No. 2 November 2013. Hal.157-195.

Firdaus, M., Lukman, M baga, Purdiyanti, Pratiwi. 2008. Swasembada Beras Dari Masa Ke Masa; Telaah Efektivitas Kebijakan dan Perumusan Strategi Nasional. IPB Press. Bogor.

Husein Sawit, M dan I.W. Rusastra. 2005, Globalisasi dan Ketahanan Pangan di Indonesia, bagian laporan penelitian Road Map Memperkuat Ketahanan Pangan, PEM UI, Jakarta

Intriligator, M. D. 1978. Econometric Model, Techniques and Applications. Prentice-Hall Inc, New Jersey.

Kasryno, F. dan E. Pasandaran. 2004. Reposisi Padi dan Beras dalam Perekonomian Nasionaldalam Ekonomi Padi dan Beras Indonesia. Badan Penelitian dan Pengembangan Pertanian. Jakarta

Kementerian Pertanian. 2012. Road Map Diversifikasi Pangan 2011-2015, Edisi 2. Jakarta: Badan Ketahanan Pangan-Kementerian Pertanian.

Koutsoyiannis, A. (2003). Theory of Econometrics. 2nd edition.. New York: Palgrave publishers.

Krugman, P.R., and M. Obstfeld. 2002. International Economics, Theory and Policy. Addition Westey Publishing Company, USA.

Kusumaningrum Ria. 2008. Dampak Kebijakan Harga Dasar Pembelian Pemerintah Terhadap Penawaran dan Permintaan Beras Di Indonesia. Tesis Magister. Sekolah Pascasarjana, Institut Pertanian Bogor.

OECD. 2012. OECD Review of Agricultural Policies: Indonesia. 2012, OECD Publishing.

Pindiyck, R.S., dan D.L. Rubinfeld. 2007. Microeconomic. Edisi Keenam. Indeks, Jakarta.

Simatupang, P. dan I W. Rusastra. 2004. Kebijakan Pembangunan Sistem Agribisnis Padi dalam Ekonomi Padi dan Beras Indonesia. Badan Penelitian dan Pengembangan Pertanian. Jakarta 